\title{
Physico-Chemical Characteristics of Soil in three Different Areas of Maihar City
}

\section{Arvind Prasad Dwivedi}

\author{
Lecturer, Department of chemistry, Govt. Girls College Shahdol M.P
}

\begin{abstract}
Maihar is a tehsil of satna district in the state of Madhya Pradesh, India. It is known for the temple of the revered mother goddess Sharda situated in Trikut hill. The town is a road and rail junction. It is located at $24.27^{\circ} \mathrm{N} 80.75^{\circ} \mathrm{E}$. The physico-chemical parameters (i.e. temperature, $p H, E C$,) $N, P, K$ and also heavy metals $(\mathrm{Mn}, \mathrm{Co}, \mathrm{Cu}, \mathrm{Zn}, \mathrm{Ni})$ has been examined in the soil sample of Maihar tehsil in Satna District. The readings were taken with the help of Atomic Absorption Spectrophotometer (AAS) and the value of $\mathrm{Zn}, \mathrm{Cd}, \mathrm{Cu}, \mathrm{Ni}$ and Co was calculated by running standards of these metals. Various soil quality parameters were analyzed by using standard procedures. Temperature, $p H, E C, N, P$ and $K$ were found to be within the SQGL recommended level.
\end{abstract}

Keywords: Physico- chemical parameters, Soil, Maihar Tehsil, Satna District

\section{INTRODUCTION}

Maihar is a tehsil of satna district in the state of Madhya Pradesh, India. It is known for the temple of the revered mother goddess Sharda situated in Trikut hill. The town is a road and rail junction. It is located at $24.27^{\circ} \mathrm{N} 80.75^{\circ} \mathrm{E}$. It has an average elevation of 376 meter. There is an important distribution centre for infrastructure product. There are three main industries of cement manufacturing, which are a large cement plant in whole city. The factory complex and the township are situated at Sarlanagar about $8 \mathrm{~km}$ away from Maihar town on the Dhanwahi road. Two new cement factories KJS cement and Reliance cement are also setting up there cement factory here. Maihar has many educational institute affiliated with Awadhesh Pratap Singh university.

The fertility of the soil depends on the concentration of N, P, and K, organic and inorganic material. The physico-chemical Properties such as moisture content, $\mathrm{pH}, \mathrm{EC}$, Nitrogen as a Fertilizer required for the growth of plant. Potassium is used for flowering purpose also require for protein synthesis, photosynthesis. Phosphate is used for growth of root in plant ${ }^{[1]}$ Environmental hazards of many chemicals are also much concern because these chemical compound like herbicides are largely responsible for effecting the soil micro-organisms and enzymes, which are responsible for oxidization, mineralization, reduction, immobilization and turnover of nutrients and other organic compounds in soil ${ }^{[2]}$.

The most important sources of heavy metals in the environment are the anthropogenic activities such as mining, smelting procedure, steel and iron industries, chemical industries; traffic, agriculture as well as domestic activities. Chemical and metallurgical industries are the most important source of heavy metals in soils. Heavy metals are important environmental pollutants they are a threat to the environment and to human health, because they are not biodegradable as they are retained indefinitely in the ecological systems and in the food chain ${ }^{[3]}$. The physico-chemical parameters (i.e. temperature, $\mathrm{pH}, \mathrm{EC}$, ) N, P, K and also heavy metals ( $\mathrm{Mn}, \mathrm{Co}, \mathrm{Cu}, \mathrm{Zn}, \mathrm{Ni}$ ) has been examined in the soil sample of Maihar tehsil in Satna District.

\section{Material ANd MethodS}

The sampling stations were chosen at different site of the study area, for testing the soil samples were collected in polythene bags from each station. Sample should be collected in clean; dry polythene. Temperature, $\mathrm{pH}, \mathrm{N}, \mathrm{P}, \mathrm{K}$ and heavy metal analyzed in the soil samples during the month of March 2015. Various soil quality parameters were analyzed by using standard procedures ${ }^{[4-5]}$. 


\subsection{Digestion of Soil Samples for Heavy Metal Analysis}

Sieving of the soil was completed with the help of $0.5 \mathrm{~mm}$ sieves and was dried for 24 hours after drying it was made cool at room temperature. After drying soil was digested with Nitric acid and distilled water. The readings were taken with the help of Atomic Absorption Spectrophotometer (AAS) and the value of $\mathrm{Zn}, \mathrm{Cd}, \mathrm{Cu}, \mathrm{Ni}$ and $\mathrm{Co}$ was calculated by running standards of these metals. The sampling locations are presented in table -1

\section{ReSidential AREA}

\begin{tabular}{|l|l|l|l|}
\hline S.No. & Sampling Location & Depth in cm & Description of the sampling location \\
\hline 1. & Rajnagar ,Maihar & $15 \mathrm{~cm}$ & Near Indian Oil Petrol Pump, Rajnagar, Maihar \\
\hline 2. & Katni Road Maihar & $15 \mathrm{~cm}$ & Infront of BRC Bhavan Katni road maihar \\
\hline 3. & Maharaja Agrasen Chouk, Maihar & $15 \mathrm{~cm}$ & Near Maharaja Agrasen Chouk Mihar \\
\hline 4. & Maa Sharda Mandir,Maihar & $15 \mathrm{~cm}$ & Near Mata mandir,Maihar \\
\hline 5. & Maihar Bus Stand ,Maihar & $15 \mathrm{~cm}$ & Behind Nagar Palika Office,Maihar \\
\hline 6. & Sarla Nagar Road,Maihar & & Near Taxi Stand Sarla Nagar road,Maihar \\
\hline
\end{tabular}

INDUSTRIAL AREA

\begin{tabular}{|l|l|l|l|}
\hline S. No. & Sampling Location & Depth $\mathbf{( c m )}$ & Description of Sampling Location \\
\hline 1. & KJS cement Plant Gate No.2 & $15 \mathrm{~cm}$ & KJS cement Plant Rajnagar ,Maihar \\
\hline 2. & $\begin{array}{l}\text { Birla Gold Cement Plant,Sarlanagar, } \\
\text { Maihar }\end{array}$ & $15 \mathrm{~cm}$ & Near transport office,KJs Cement Plant, Maihar \\
\hline 3. & $\begin{array}{l}\text { Reliance cement plant } \\
\text { Bharouli,Maihar }\end{array}$ & $15 \mathrm{~cm}$ & Near ETP plant, Reliance cement plant,Maihar \\
\hline
\end{tabular}

\section{CROP LAND AREA}

\begin{tabular}{|l|l|l|l|}
\hline S. No. & Sampling Location & Depth $(\mathbf{c m})$ & Description of Sampling station \\
\hline 1. & Vill-Sonavari, Maihar & $15 \mathrm{~cm}$ & Near Sonvari cropland area \\
\hline 2. & Kherva Railway crossing, Maihar & $15 \mathrm{~cm}$ & Near Kherva railway crossing, Bharouli ,Maihar \\
\hline 3. & Near Vill- Jeetnagar,Maihar & $15 \mathrm{~cm}$ & Infront of Bharat Petrol pump,Jeetnagar, Maihar \\
\hline 4. & Vill- Pondi Maihar & $15 \mathrm{~cm}$ & Near Aanganvadi centre, Pondi Maihar \\
\hline 5. & $\begin{array}{l}\text { Near Swami vivekanand vidyapeeth, } \\
\text { Maihar }\end{array}$ & $15 \mathrm{~cm}$ & Vill-Oila Satna Road, Maihar \\
\hline 6. & Vill-Rajnagar,Riwa Road ,Maihar & $15 \mathrm{~cm}$ & Near Bear Beal Public School, Rajnagar, Maihar \\
\hline
\end{tabular}

\section{RESUlt AND DISCUSSION}

In the present study fifteen soil Samples were collected from three different areas of Maihar City. Analysis Physico-chemical characteristics of soil in Maihar tehsil of Satna district, all the results are shown in-table 2and figure-1 to 33.

\subsection{Temperature, $\mathrm{pH}$ and $\mathrm{EC}$}

Temperature of all soil samples shows variation between $26.5^{\circ} \mathrm{C}$ to $36.2^{\circ} \mathrm{C}$. The maximum temp value (36.2) was detected in ( $\mathrm{MSI}_{1}$ ) KJS cement plant and minimum temp value (26.5) was recorded in $\left(\mathrm{MSC}_{2}\right)$ near kherva railway crossing. $\mathrm{pH}$ concentration was observed between 6.95 to 7.90 range. The highest $\mathrm{pH}$ value (7.90) was analysed in $\left(\mathrm{MSI}_{1}\right)$ KJS cement plant. Tripathi et al, $2015^{[6]}$ determined of soil in Sidhi District and reported the $\mathrm{pH}$ concentration of soil is 5.6 to 8.4. Electrical conductivity shows variation between 0.04 to $0.47 \mathrm{mhos} / \mathrm{cm}$. The high $\mathrm{EC}$ value $(0.47)$ was recorded in $\left(\mathrm{MSC}_{2}\right)$ near kherva railway crossing and low EC value (0.04) was observed in $\left(\mathrm{MSR}_{1}\right)$ near Indian oil petrol pump, Rajnagar.Mandal et al, $201{ }^{[7]}$ studied Nagpurpur soil and recorded EC 0.21 to $0.49 \mathrm{mhos} / \mathrm{cm}$.

\subsection{Nitrogen, Phosphorous and Potassium}

In the present study nitrogen concentration were recorded ranged from 4.2 to $30.10 \mathrm{mg} / \mathrm{kg}$. The highest nitrogen content (30.10) was detected in $\left(\mathrm{MSR}_{6}\right)$ near taxi stand sarlanagar. The phosphorous concentration in soil varied between 0.18 to $4.89 \mathrm{mg} / \mathrm{kg}$. Maximum concentration of phosphorous (4.89) was detected in $\left(\mathrm{MSI}_{3}\right)$ Reliance cement plant,Bharauli,Maihar and minimum concentration of Phosphorous (0.18) was recorded in $\left(\mathrm{MSR}_{1}\right)$ Near rajnagar Maihar. The concentration of Potassium in all soil samples varied from 3.9 to $19.6 \mathrm{mg} / \mathrm{kg}$. The highest potassium content (19.6) was observed in $\left(\mathrm{MSC}_{5}\right)$ near vill Oila Satna Road Maihar. Concentrations of Nitrogen, Phosphorous and Potassium for the samples were below the recommended level. Tripathi et al, $2014^{[8]}$ studied Umaria soil and reported nitrogen, phosphorous and potassium are found to be 8.86 to $41.50,0.25$ to $1.16,30$ to $70 \mathrm{mg} / \mathrm{kg}$. 


\subsection{Heavy Metal Analysis}

Concentration of manganese, Iron and Zinc ranged from 1.25 to $12.49 \mathrm{mg} / \mathrm{kg}, 8.9$ to $73.0 \mathrm{mg} / \mathrm{kg}$, and 10.08 to $22.26 \mathrm{mg} / \mathrm{kg}$ respectively. The maximum manganese concentration (12.49) was detected in $\left(\mathrm{MSI}_{2}\right)$ Birla gold cement plant Maihar and the highest iron concentration (73.0) was observed in $\left(\mathrm{MSC}_{3}\right)$ near aanganvadi centre, Pondi Maihar. The maximum Zinc concentration (22.26) was detected in $\left(\mathrm{MSC}_{2}\right)$ near kherva railway crossing. The concentrations of Manganese, Zinc, and Iron for all the samples were below the recommended level as $20 \mathrm{mg} / \mathrm{kg}, 200 \mathrm{mg} / \mathrm{kg}$, and $380 \mathrm{mg} / \mathrm{kg}$ respectively. Shivakumar et al, 2012 ${ }^{[9]}$ studied physico-chemical profile of soil along the banks of Amaravati river banks in Karur areas of Tamil Nadu and reported iron content range between 6.14 to $9.85 \mathrm{mg} / \mathrm{kg}$

Concentration of cobalt in soil samples ranging from 2.3 to $21.5 \mathrm{mg} / \mathrm{kg}$. Samples $\left(\mathrm{MSI}_{1}\right) \mathrm{KJS}$ cement plant (21.5), $\left(\mathrm{MSI}_{2}\right)$ Birla gold cement plant (18.6), $\left(\mathrm{MSR}_{3}\right)$ Maharaja Agrasen chouk (10.4), $\left(\mathrm{MSC}_{2}\right)$ near kherva railway crossing (15.8) exceed the permissible limit set by SQGL value. Krishna ${ }^{[10]}$ et al, 2005 studied Thane Belapur Industrial Area Soil and reported cobalt concentration is found to be 44.8 to $101.6 \mathrm{mg} / \mathrm{kg}$.

Copper Concentration in soil varied between 4.3 to $92.6 \mathrm{mg} / \mathrm{kg}$. The highest copper concentration (92.6) was observed in $\left(\mathrm{MSI}_{1}\right) \mathrm{KJS}$ cement plant while lowest copper concentration (4.3) was analysed in $\left(\mathrm{MSR}_{4}\right)$ Maa Sharda Mandir Maihar. Values of copper concentration at sampling station $\left(\mathrm{MSI}_{1}\right) \mathrm{KJS}$ cement plant (92.6) and $\left(\mathrm{MSI}_{2}\right)$ Birla gold cement plant (87.4) are above permissible limit prescribed by SQGL value. Tripathi et al, $2013^{[11]}$ studied the characterization of diffuse chemical pollution and reported that concentration of copper ranged from 0.25 to $87.20 \mathrm{mg} / \mathrm{kg}$.

Table2. Physico-chemical Characteristics of Soil in Three Different Area of Maihar City

\begin{tabular}{|c|c|c|c|c|c|c|c|c|c|c|c|c|}
\hline \multicolumn{2}{|c|}{ Parameter } & Temp & pH & \begin{tabular}{|c|} 
EC \\
mhos/cm
\end{tabular} & $\begin{array}{c}\mathrm{N} \\
\mathrm{mg} / \mathrm{kg}\end{array}$ & $\begin{array}{c}P \\
\mathrm{mg} / \mathrm{kg}\end{array}$ & $\begin{array}{c}\mathrm{K} \\
\mathrm{mg} / \mathrm{kg}\end{array}$ & \begin{tabular}{|c|}
$\mathrm{Mn}$ \\
$\mathrm{mg} / \mathrm{kg}$
\end{tabular} & $\begin{array}{c}\mathrm{Fe} \\
\mathrm{mg} / \mathrm{kg}\end{array}$ & $\begin{array}{c}\mathrm{Co} \\
\mathrm{mg} / \mathrm{kg}\end{array}$ & \begin{tabular}{|c|}
$\mathrm{Cu}$ \\
$\mathrm{mg} / \mathrm{kg}$
\end{tabular} & $\begin{array}{c}\mathrm{Zn} \\
\mathrm{mg} / \mathrm{kg}\end{array}$ \\
\hline \multirow{3}{*}{$\begin{array}{l}\text { Industrial } \\
\text { site }\end{array}$} & MSI1 & 36.2 & 7.90 & 0.10 & 8.2 & 0.26 & 14.2 & 8.71 & 63.4 & 21.5 & 92.6 & 16.2 \\
\hline & MSI2 & 32.5 & 7.28 & 0.32 & 28.35 & 1.52 & 9.5 & 12.49 & 56.0 & 18.6 & 87.4 & 11.8 \\
\hline & MSI3 & 30.4 & 7.21 & 0.06 & 19.10 & 4.89 & 12.7 & 6.85 & 29.0 & 6.2 & 55.2 & 10.08 \\
\hline \multirow{6}{*}{$\begin{array}{l}\text { Residential } \\
\text { Site }\end{array}$} & MSR1 & 26.5 & 7.30 & 0.04 & 21.9 & 0.18 & 5.6 & 5.85 & 11.6 & $\mathrm{ND}$ & 7.5 & $\mathrm{ND}$ \\
\hline & MSR2 & 30.2 & 7.43 & 0.19 & 6.31 & 0.76 & 17.5 & 10.3 & 8.9 & 5.6 & ND & 21.62 \\
\hline & MSR3 & 27.0 & 7.10 & 0.11 & 16.0 & 0.20 & 15.0 & 4.33 & 24.1 & 10.4 & 11.3 & $\mathrm{ND}$ \\
\hline & MSR4 & 26.7 & 7.08 & 0.15 & 14.6 & 1.26 & $\mathrm{ND}$ & 1.25 & 32.0 & 2.3 & 4.3 & 13.4 \\
\hline & MSR5 & 28.0 & 7.33 & 0.08 & 8.4 & 0.27 & 9.8 & 6.41 & 17.5 & $\mathrm{ND}$ & ND & ND \\
\hline & MSR6 & 30.0 & 7.68 & 0.33 & 30.10 & 0.36 & ND & 7.50 & 10.0 & 4.5 & 32.1 & ND \\
\hline \multirow{6}{*}{$\begin{array}{l}\text { Cropland } \\
\text { Site }\end{array}$} & MSC1 & 28.6 & 7.21 & 0.25 & 11.6 & 0.23 & 16.0 & 5.66 & 36.3 & 7.2 & 27.5 & 13.20 \\
\hline & MSC2 & 26.5 & 7.18 & 0.47 & 19.3 & 1.16 & 12.7 & 4.53 & 27.2 & 15.8 & 16.6 & 22.26 \\
\hline & MSC3 & 27.8 & 7.20 & 0.14 & 4.2 & 0.49 & 9.7 & 5.40 & 73.0 & 3.6 & ND & 16.52 \\
\hline & MSC4 & 27.0 & 6.95 & 0.19 & 21.5 & 3.13 & 11.6 & 6.31 & 42.1 & 2.8 & 9.0 & 21.48 \\
\hline & MSC5 & 28.3 & 7.35 & 0.12 & 18.3 & 2.79 & 19.6 & 9.75 & 30.7 & 5.4 & 5.8 & 15.32 \\
\hline & MSC6 & 31.1 & 6.98 & 0.16 & 7.4 & 0.56 & 3.9 & 9.81 & 23.8 & $\mathrm{ND}$ & ND & 11.0 \\
\hline \multirow[t]{3}{*}{ Mean } & Mean & \begin{tabular}{|l|}
29.120 \\
\end{tabular} & 7.279 & 0.181 & 15.684 & 1.236 & 12.138 & 7.010 & 32.373 & 8.658 & 31.755 & 15.716 \\
\hline & S.D. & 2.693 & 0.250 & 0.117 & 7.963 & 1.407 & 5.959 & 2.834 & 19.215 & 6.780 & 31.060 & 8.096 \\
\hline & C.V. & 9.247 & 3.434 & 65.002 & 50.77 & 113.898 & 49.089 & 40.434 & 59.352 & 78.3 & 97.811 & 51.509 \\
\hline
\end{tabular}

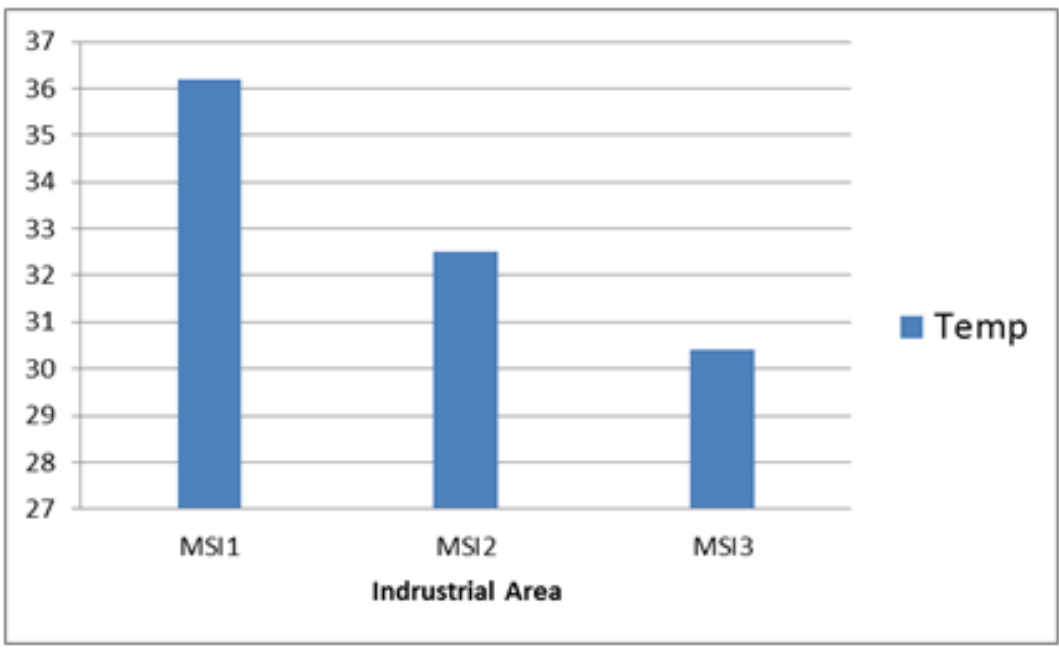

Figure1. Temperature of soil in Industrial Area of Maihar City 


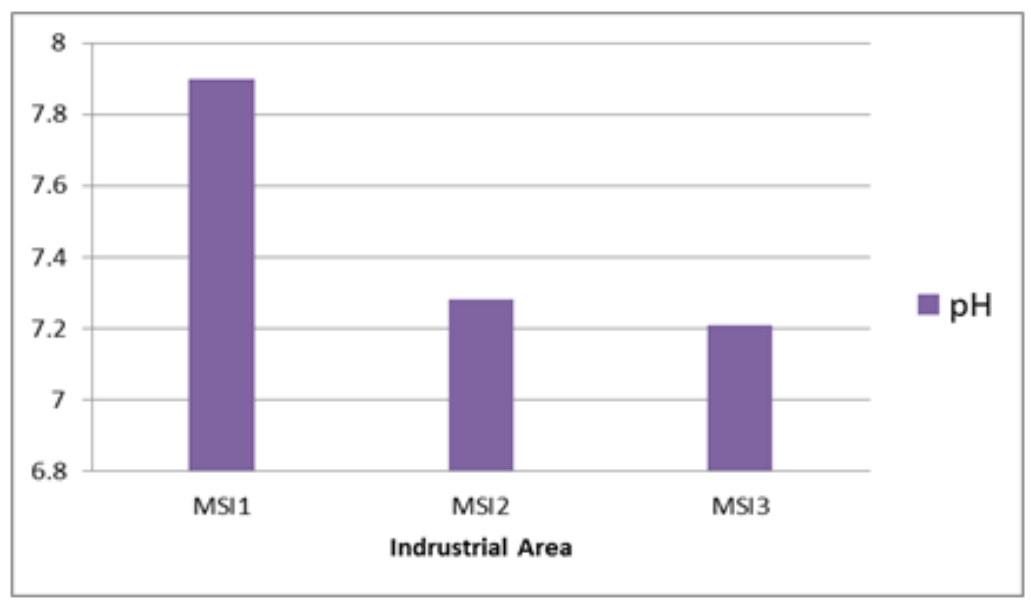

Figure2. $p H$ Concentration of soil in Industrial Area of Maihar City

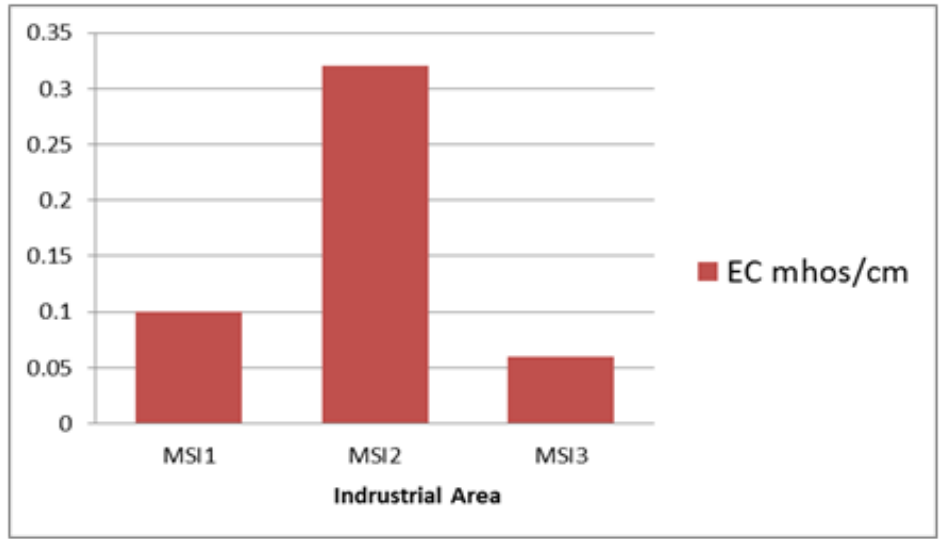

Figure3. EC of soil in Industrial Area of Maihar City

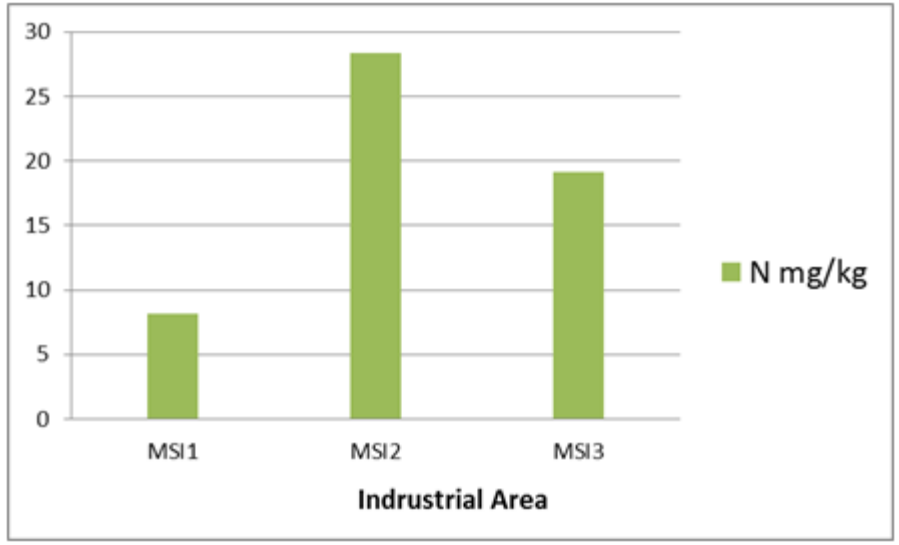

Figure4. Nitrogen Concentration of soil in Industrial Area of Maihar Ci

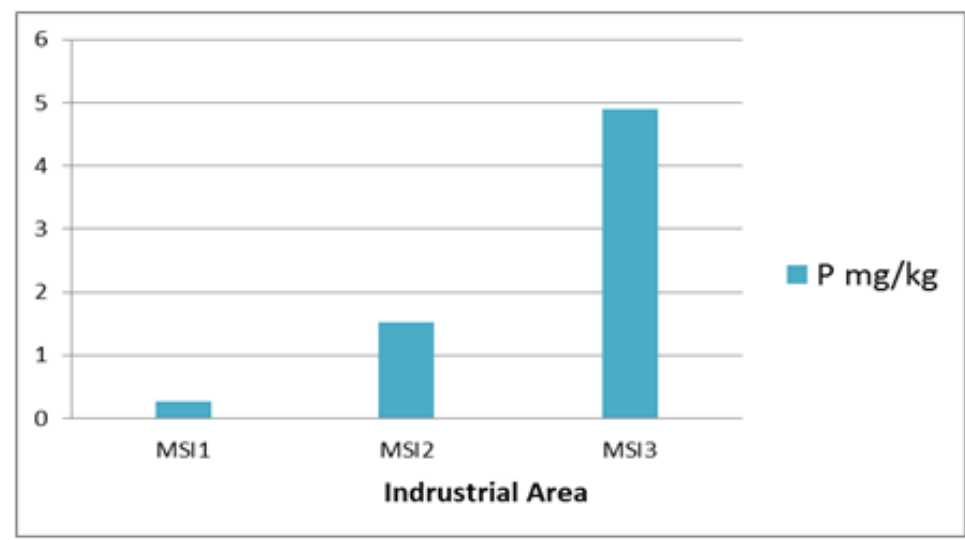

Figure5. Phosphorus concentration of soil in Industrial Area of Maihar City 
Physico-Chemical Characteristics of Soil in three Different Areas of Maihar City

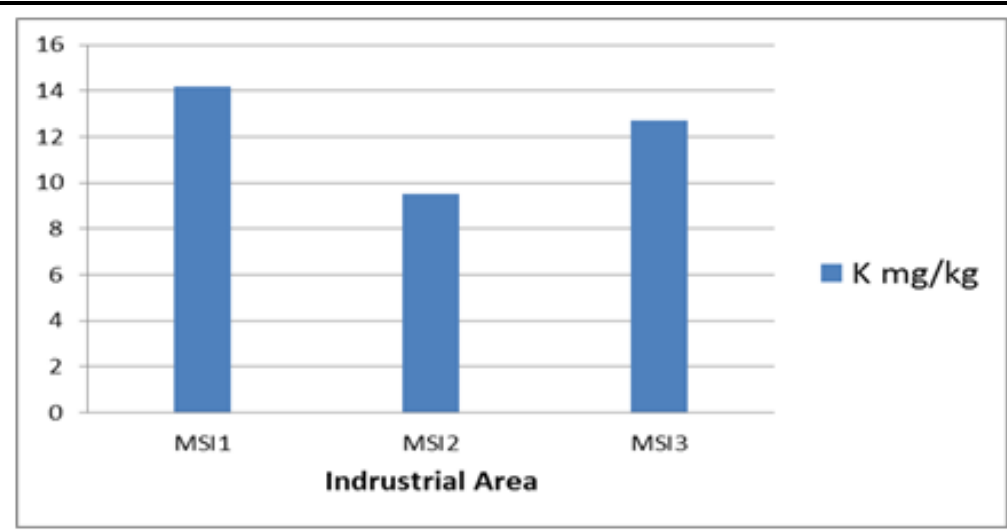

Figure6. Potassium concentration of soil in Industrial Area of Maihar City

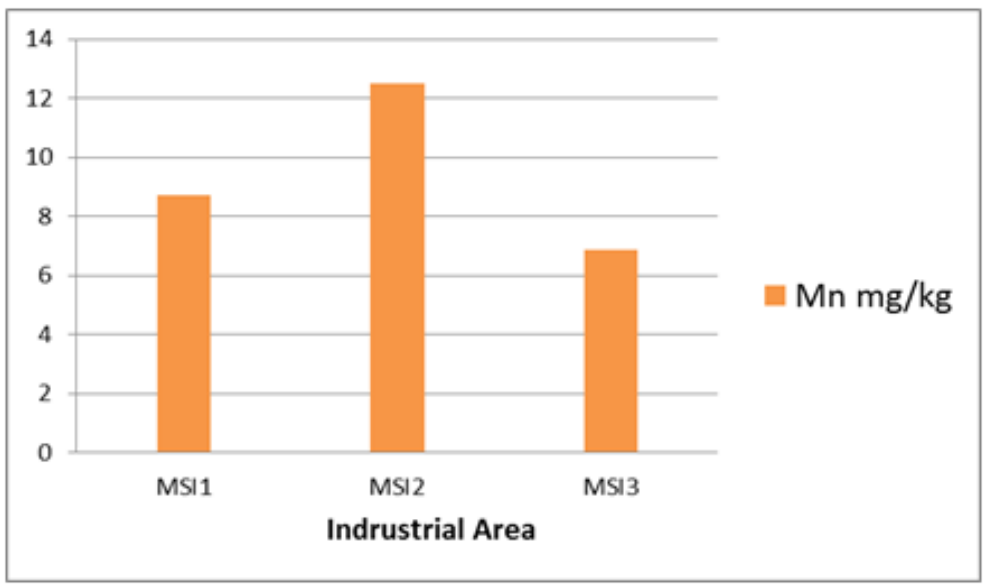

Figure7. Magnus concentration of soil in Industrial Area of Maihar City

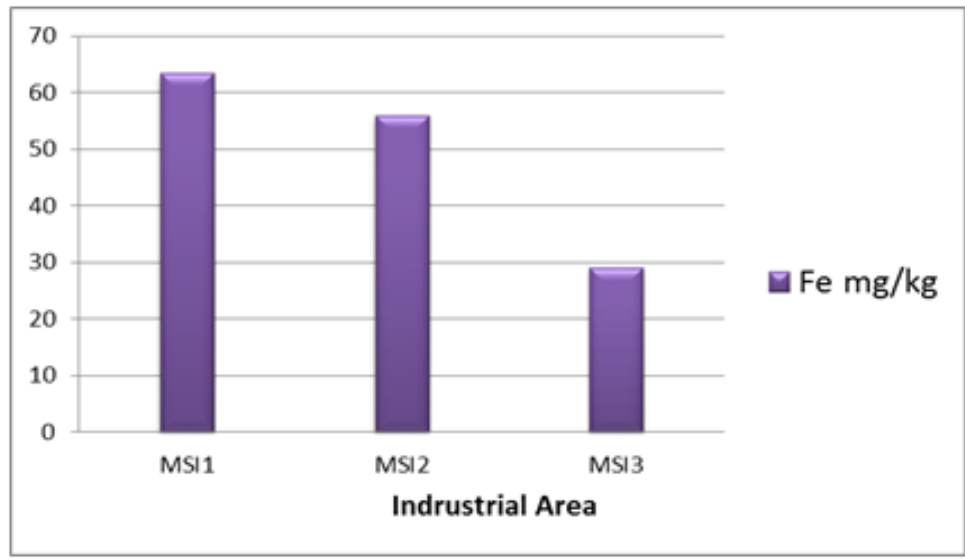

Figure8. Iron concentration of soil in Industrial Area of Maihar City

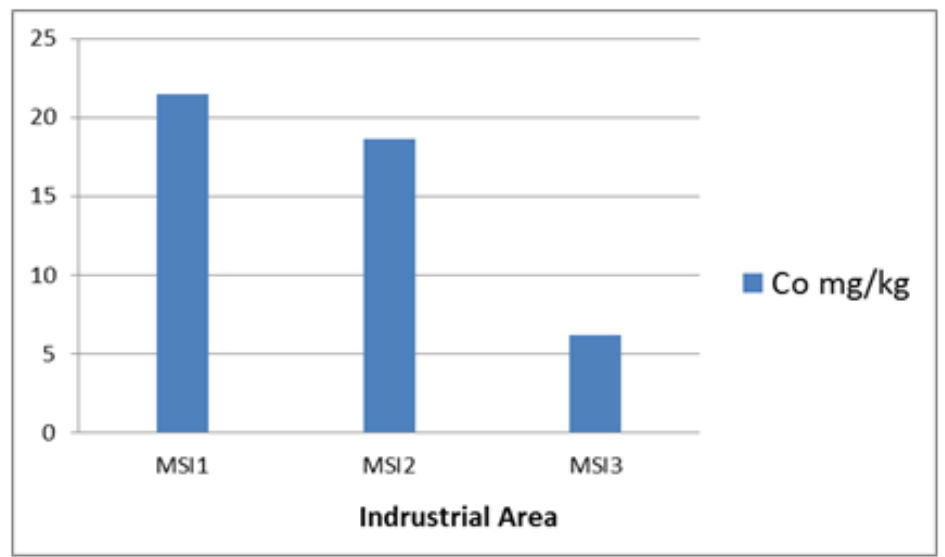

Figure9. Cobalt concentration of soil in Industrial Area of Maihar City 


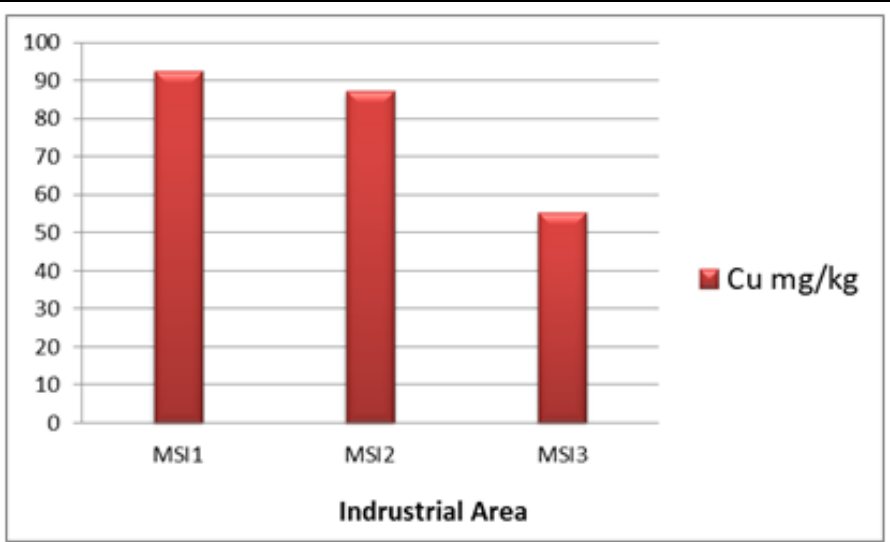

Figure10. Copper concentration of soil in Industrial Area of Maihar City

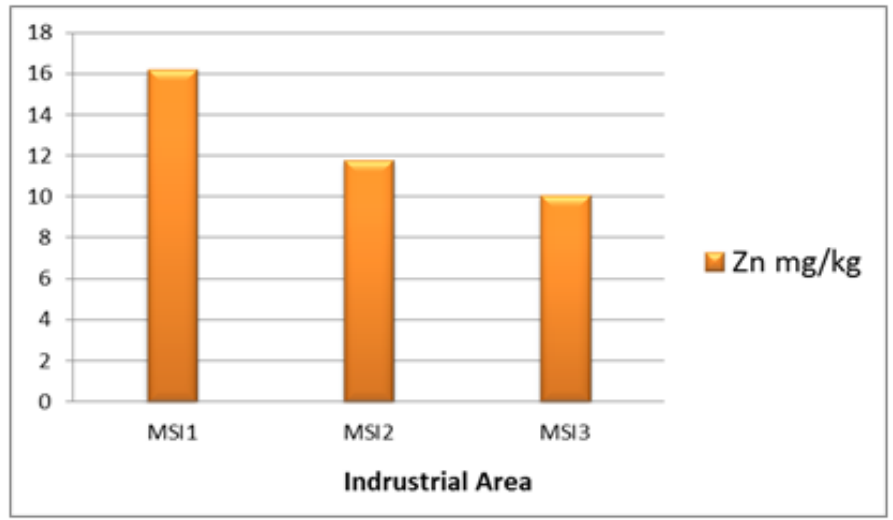

Figure11. Zinc concentration of Soil in Industrial Area of Maihar City

\section{RESidential AREA:}

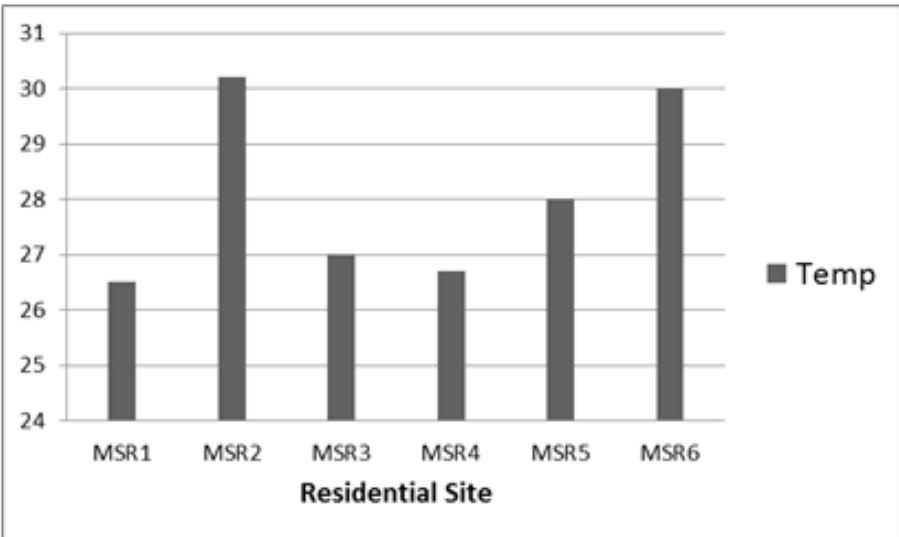

Figure12. Temperature of soil in Residential Area of Maihar City

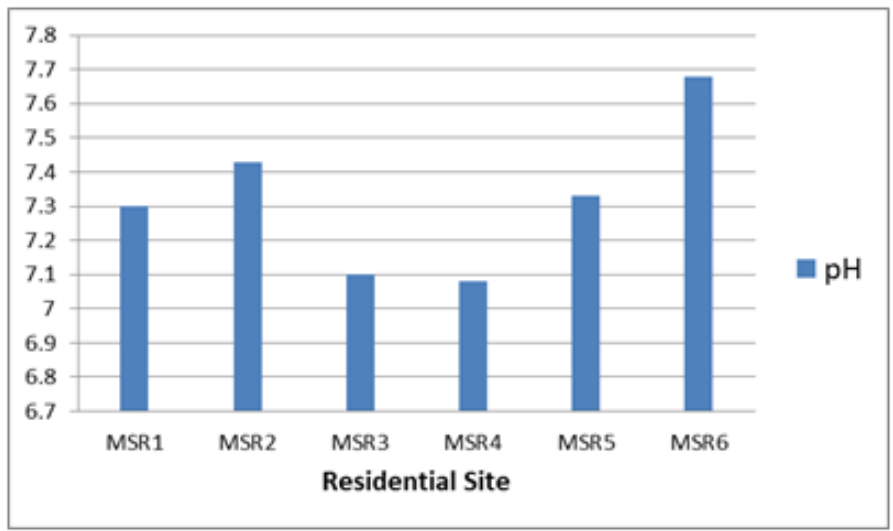

Figure13. $p H$ Concentration of soil in Residential Area of Maihar City 
Physico-Chemical Characteristics of Soil in three Different Areas of Maihar City

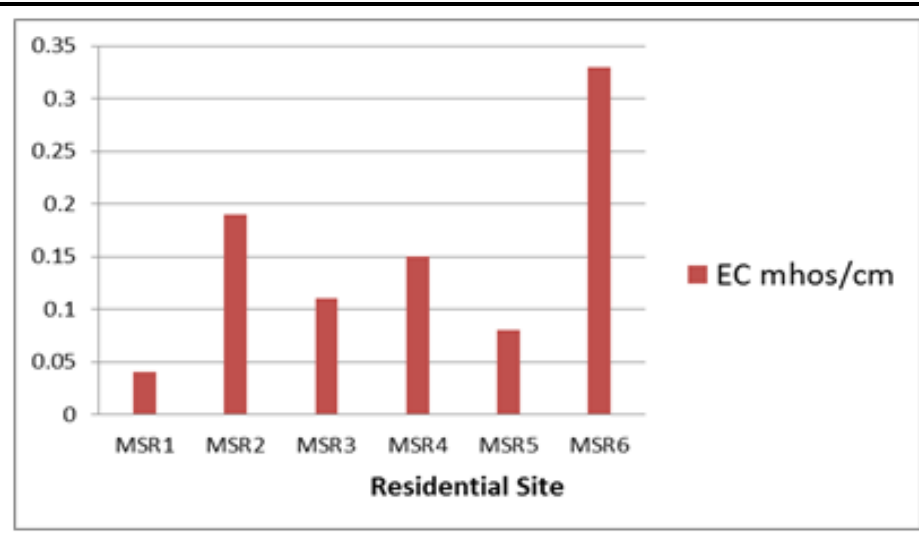

Figure14. EC of soil in Residential Area of Maihar City

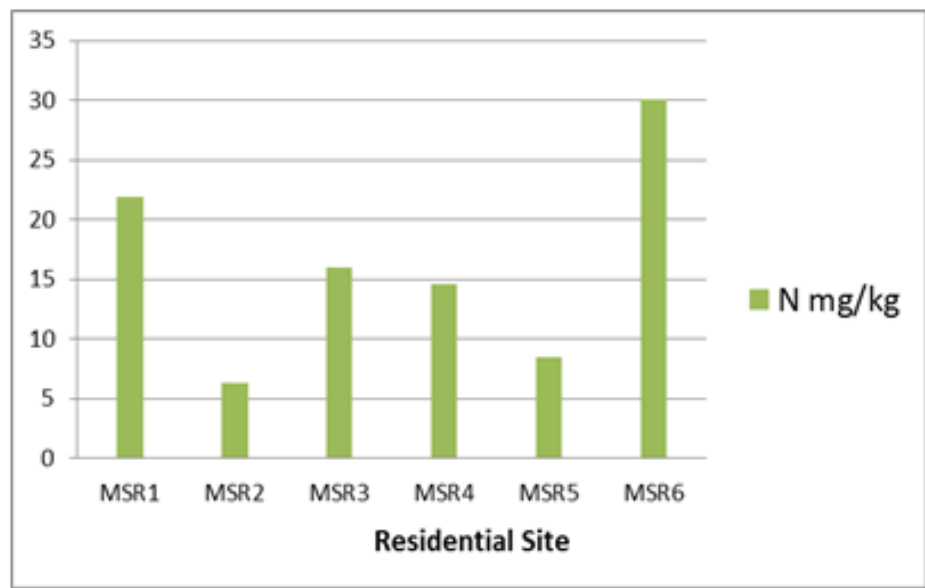

Figure15. Nitrogen Concentration of soil in Residential Area of Maihar City

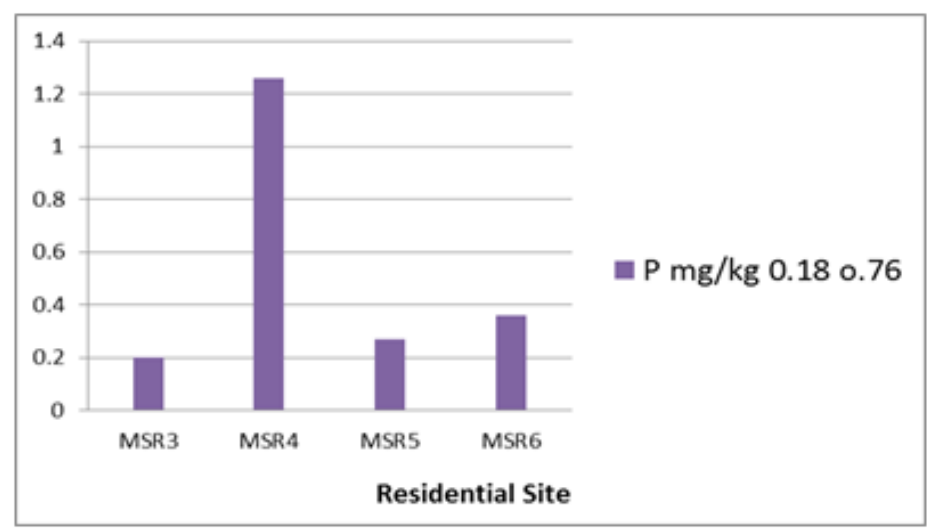

Figure16. Phosphorus Concentration of soil in Residential Area of Maihar City

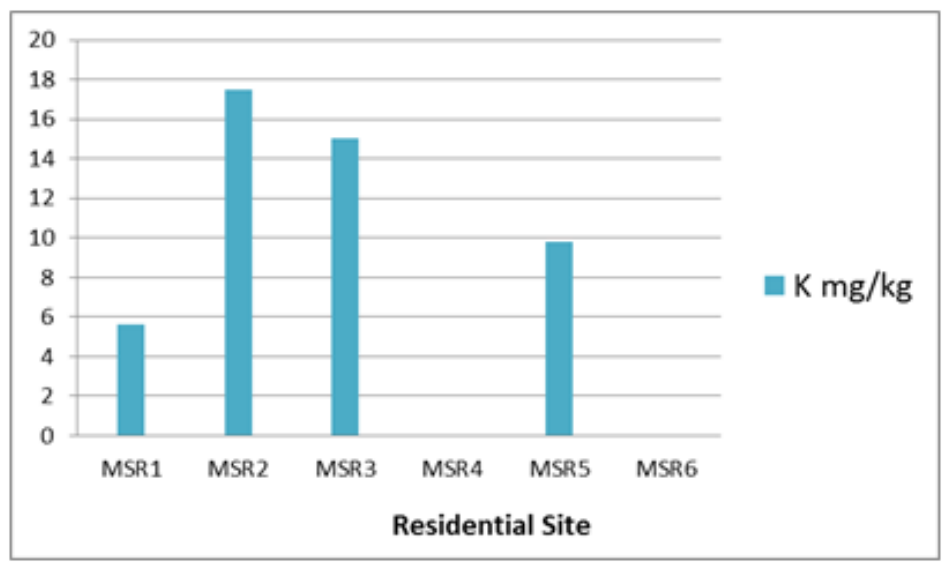

Figure17. Potassium concentration of soil in Residential Area of Maihar City 


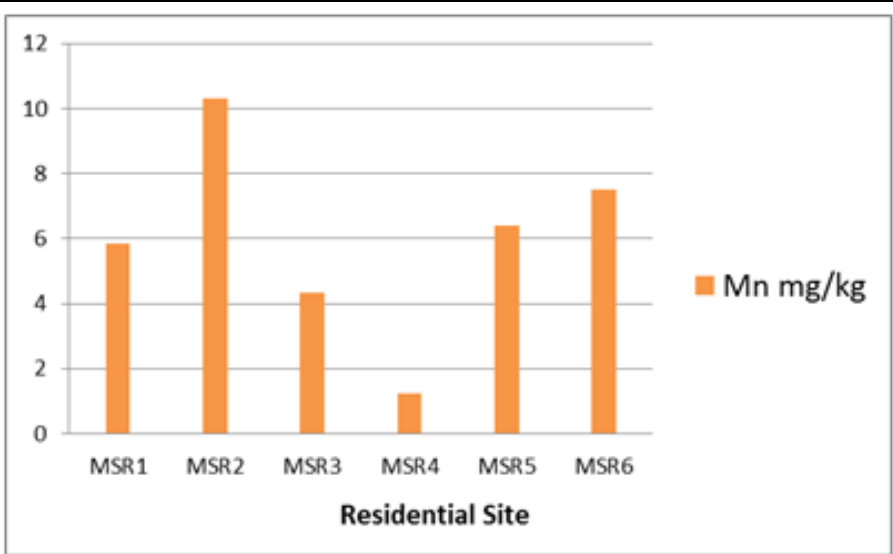

Figure18. Magnus concentration of soil in Residential Area of Maihar City

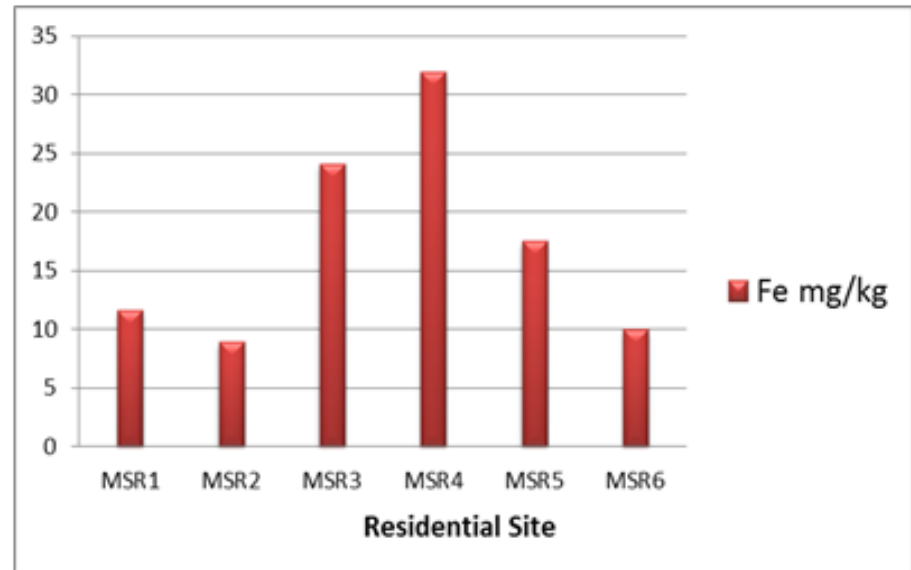

Figure19. Iron concentration of soil in Residential Area of Maihar City

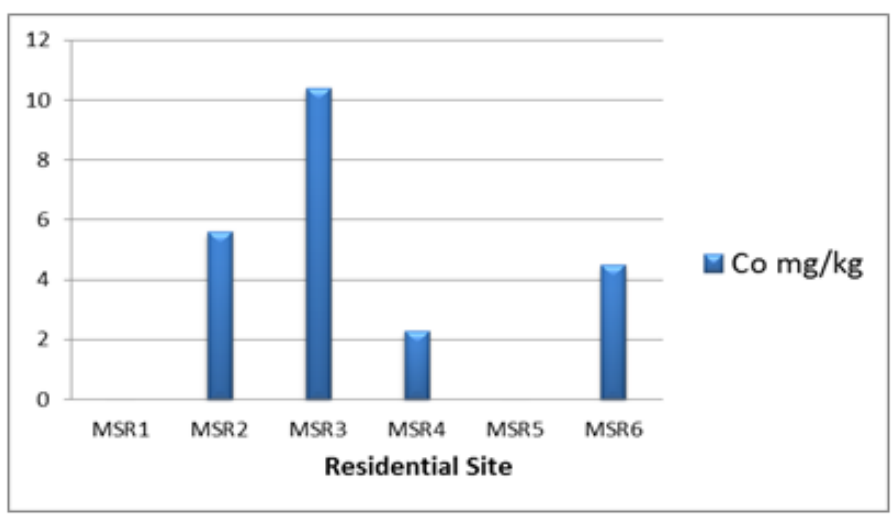

Figure20. Cobalt concentration of soil in Residential Area of Maihar City

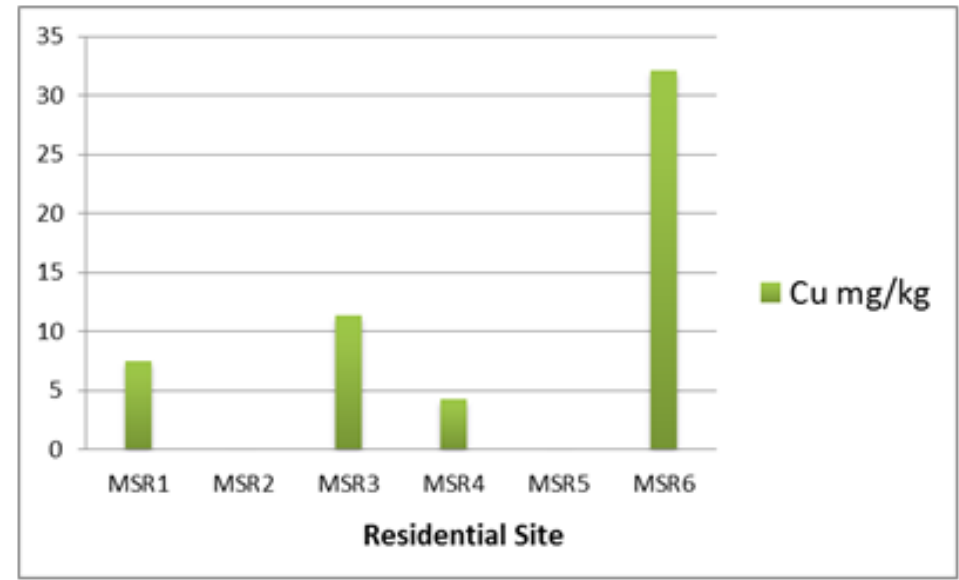

Figure21. Copper concentration of soil in Residential Area of Maihar City 


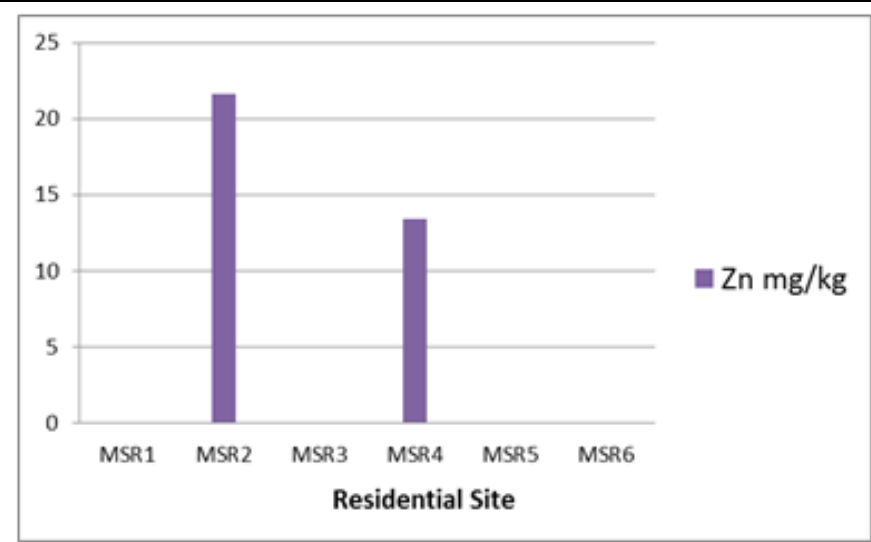

Figure22. Zinc concentration of Soil in Residential Area of Maihar City

\section{Cropland Area}

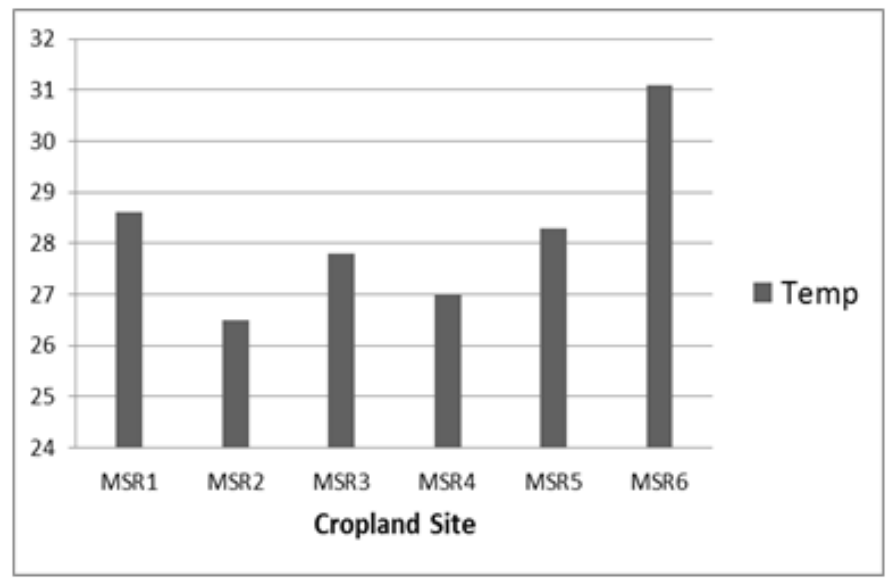

Figure23. Temperature of soil in Cropland Area of Maihar City

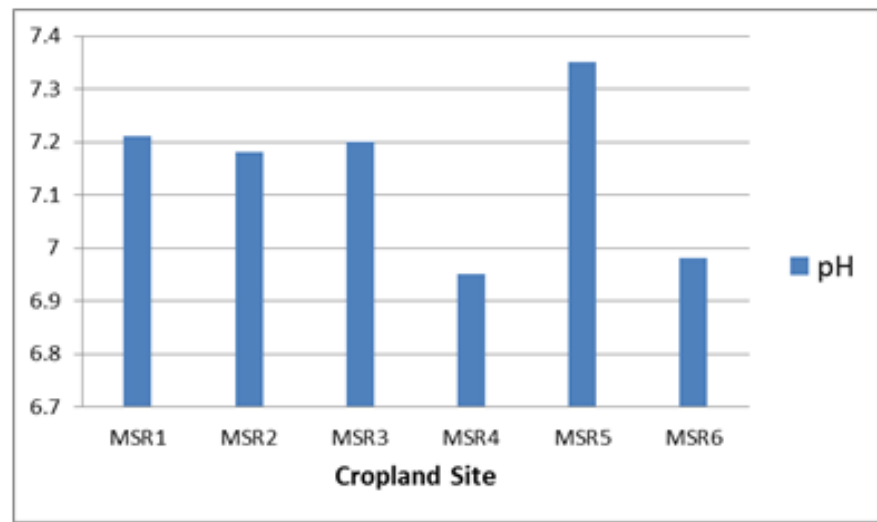

Figure24. pH Concentration of soil in Cropland Area of Maihar City

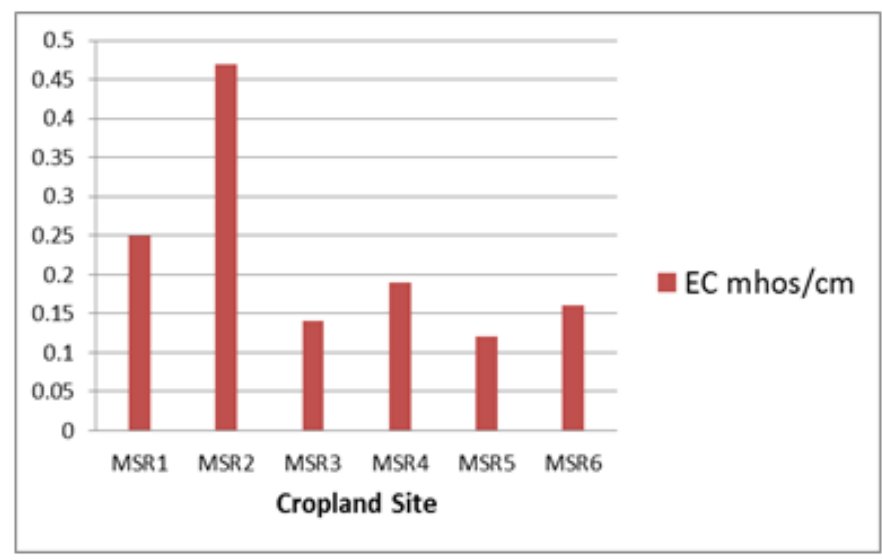

Figure25. EC of soil in Cropland Area of Maihar City 


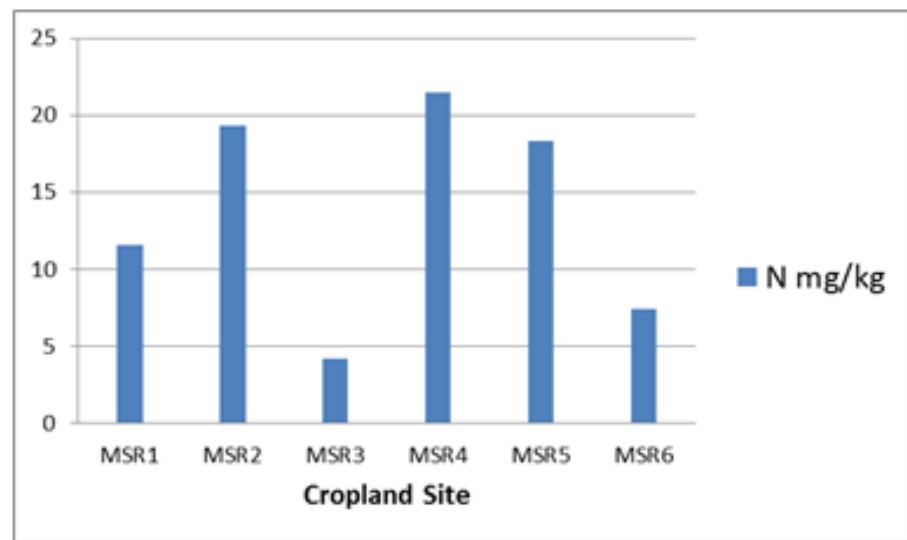

Figure26. Nitrogen Concentration of soil in Cropland Area of Maihar City

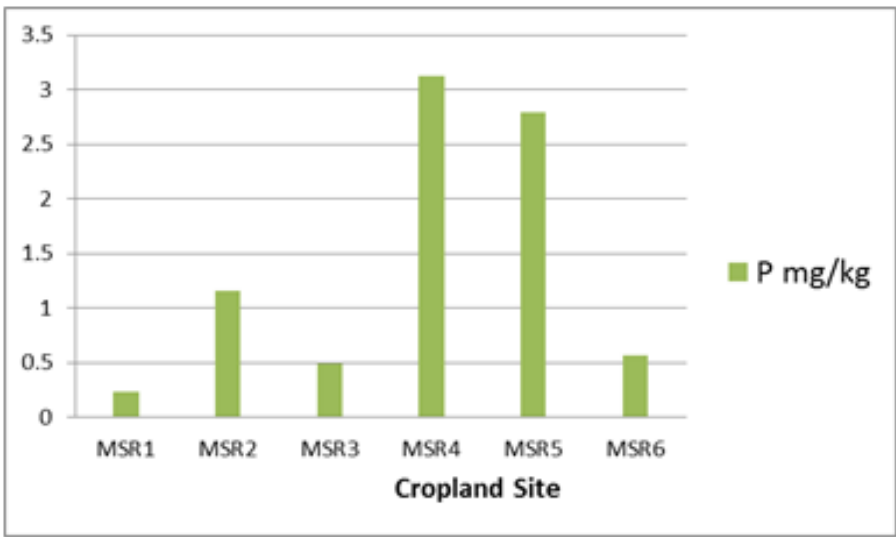

Figure27. Phosphorus concentration of soil in Cropland Area of Maihar City

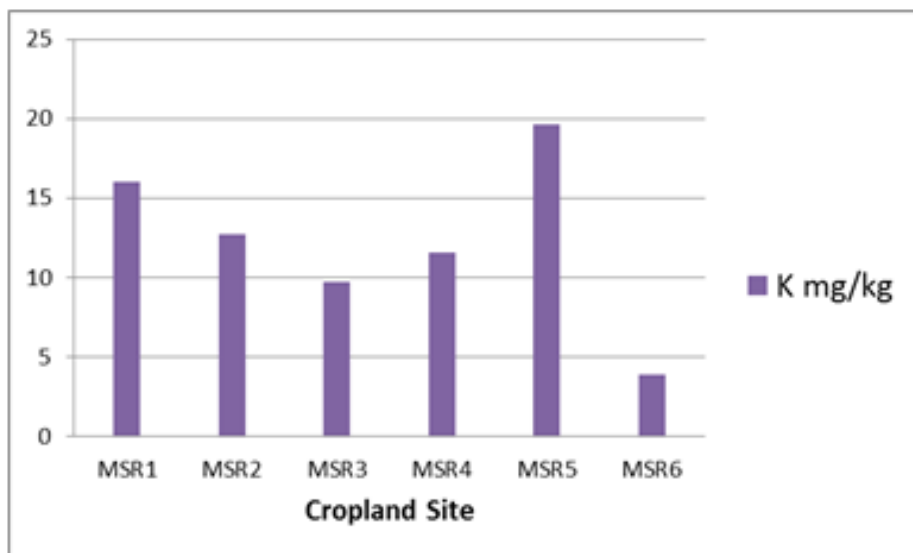

Figure28. Potassium concentration of soil in Cropland Area of Maihar City

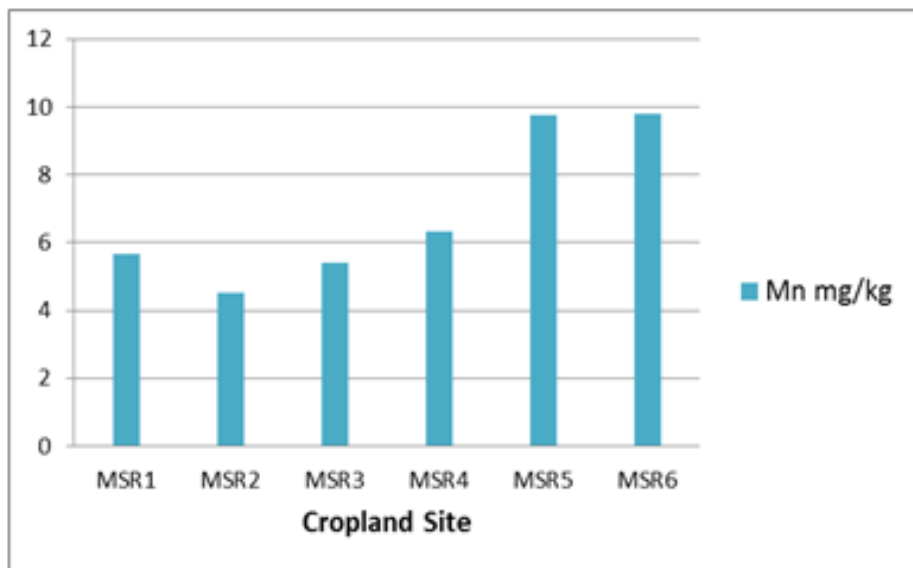

Figure29. Magnus concentration of soil in Cropland Area of Maihar City 


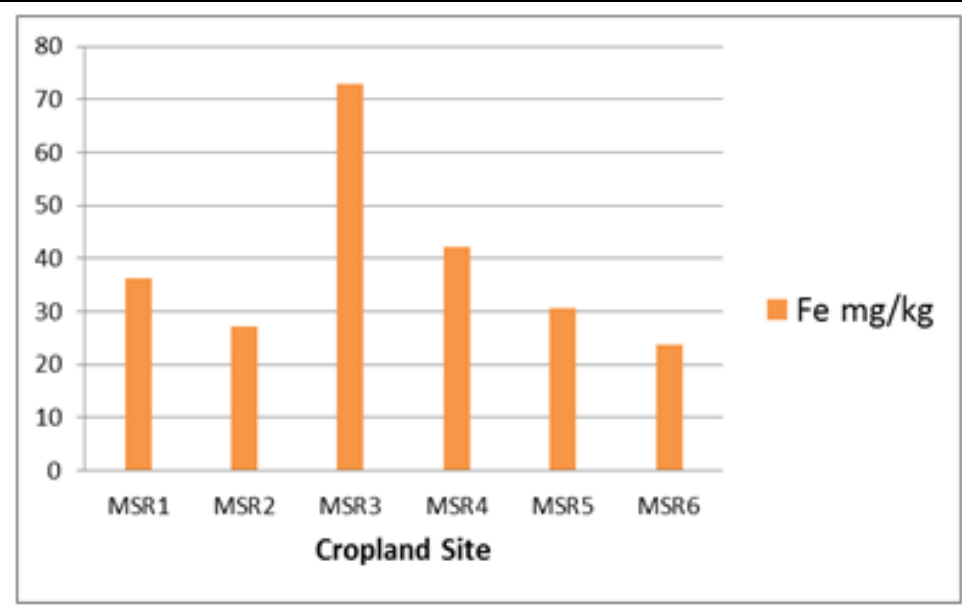

Figure30. Iron concentration of soil in Cropland Area of Maihar City

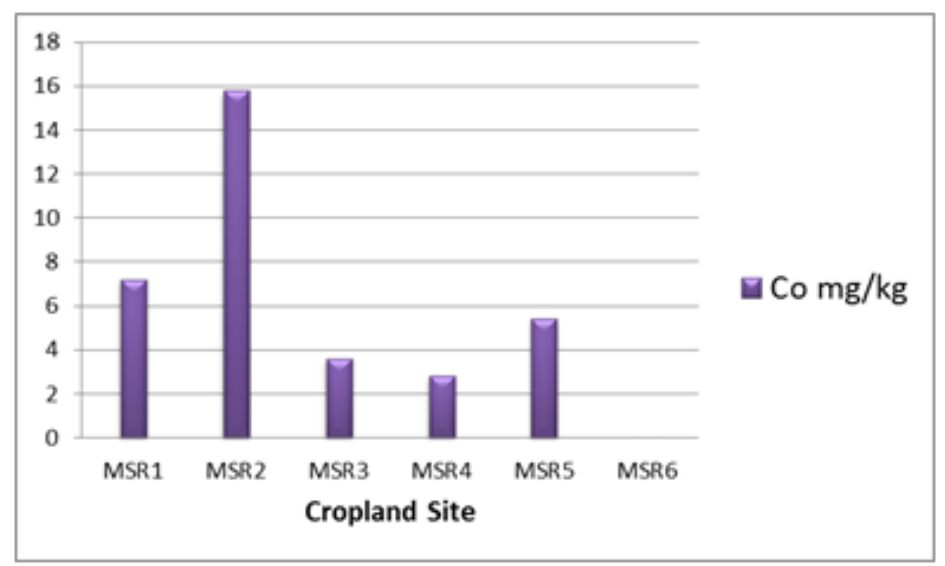

Figure31. Cobalt concentration of soil in Cropland Area of Maihar City

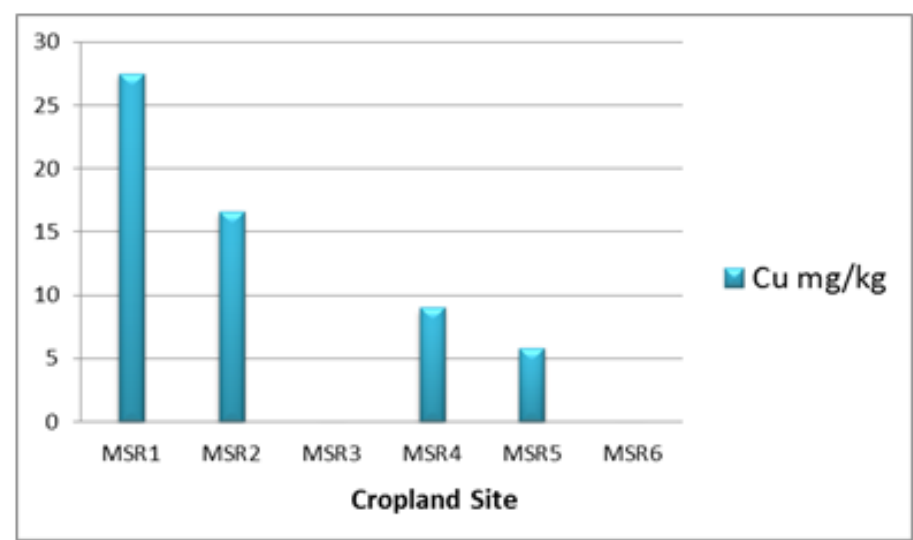

Figure32. Copper concentration of soil in Industrial Area of Maihar City

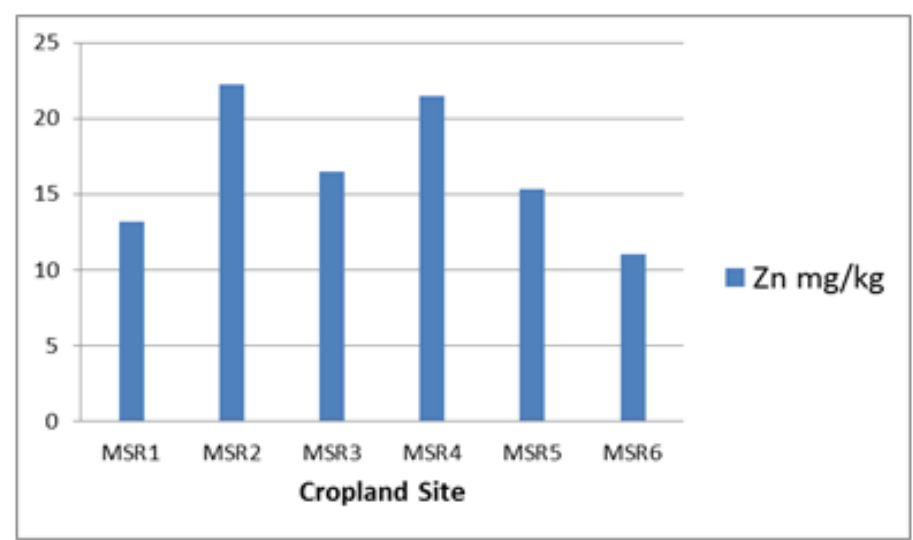

Figure33. Zinc concentration of Soil in Industrial Area of Maihar City 


\section{Conclusions}

Fifteen Soil samples were collected from Maihar city. Laboratory tests such as Temperature, $\mathrm{pH}, \mathrm{EC}, \mathrm{N}$, $\mathrm{P}, \mathrm{K}, \mathrm{Mn}, \mathrm{Fe}, \mathrm{Co}, \mathrm{Cu}$ and $\mathrm{Zn}$ etc were performed for the analysis of soil samples. All the results are compared with soil quality standard. Temperature, $\mathrm{pH}, \mathrm{EC}, \mathrm{N}, \mathrm{P}$ and $\mathrm{K}$ were found to be within the SQGL recommended level. Cobalt concentration at sampling station $\left(\mathrm{MSI}_{1}\right) \mathrm{KJS}$ cement Plant, $\left(\mathrm{MSI}_{2}\right)$ Birla Gold Cement plant, $\left(\mathrm{MSR}_{3}\right)$ Maharaja Agrasen chouk, $\left(\mathrm{MSC}_{2}\right)$ near kherva railway crossing are found more than the SQGL recommended Level. Copper concentrations were found at all the sampling station were below the recommended level except (MSI $)$ KJS cement plant and $\left(\mathrm{MSI}_{2}\right)$ Birla gold cement plant. From obtain results it is suggested to monitor the soil quality and assess periodically to prevent the further contamination.

\section{REFERENCES}

[1] KP Kordlaghari; SN Sisakht; A Saleh; Annals of Biological Research, 4(3), 105-108, 2013.

[2] Bansal O. P., Influence of three Carbamate Pesticides on Mn and Fe status of Saline Sodic Soil of Aligarh. Part-1 J. Indian Chem. Soc., 79, 671-680, 2002.

[3] Thakre,Y.G. Choudhary, M. D. and Raut R. D. Physico-chemical characterization of red and black soil of Wardha region, International Journal of chemical and Physical Science, 1:60-66,2012

[4] A.K. Dc, Environmental chemistry, New Age International publisher, New Delhi, 4th Edition 1982

[5] Piper C. S., A Laboratory Manual of Methods for the Examination of Soil and the Determination of the Inorganic Constituents of Plant, original edition 1942.

[6] Indra Prasad Tripathi and Arvind Prasad Dwivedi, Multivariate Analysis of Soil and Ground water quality in Sidhi District of Vindhya Plateau, Journal of Applicable Chemistry,4:178-203, 2015.

[7] A.K.Sahoo, Dipak sarkar, U. Bruah and P.S.Butte, Characterization, Classification and Evaluation of soils of Langol Hill, Manipur for rational land use planning. Journal of the Indian Society of soil Science. 58 (4): 355-362, 2010.

[8] Indra Prasad Tripathi, M. Suresh Kumar, Arvind Prasad Diwedi, Concentration of Cr, Pb, Cd, Ni, $\mathrm{Cu}$ and $\mathrm{Fe}$ in soil of Umaria District, Vindhya Platue, India, International Indexed \& Refereed Research Journal , 5, 28-32, 2014.

[9] Sivakumar, K. K. and Ms. Dheendayalan,.Studied Physico-chemical profile of soil along the bank of Amaravati riverbanks in Karur areas of Tamil Nadu.journal IJEP. 32,504-509, 2012.

[10] A. K. Krishna and P.K. Govil, Heavy Metal Distribution and Contamination in Soils of ThaneBelapur Industrial Development Area, Mumbai western, India, Journal Environmental Geology, 47,1054-1061, 2005.

[11] Tripathi, Indra Prasad Kumar, M. Suresh and Dwivedi Arvind Prasad. Characterization of diffuse chemical pollution in satna district of vindhya region, India, International Research journal of Environment Science, 2, 46-60, 2013. 